\title{
Segmental phonemic system of Riau Malay subdialect Kepulauan as local knowledge in Batam
}

\author{
${ }^{1}$ Ambalegin*, ${ }^{1}$ Tomi Arianto \\ ${ }^{1}$ English language and Literature Program, Universitas Putera Batam, \\ Indonesia
}

\author{
*Corresponding Author \\ Email: abhi140475@gmail.com
}

\begin{abstract}
Malay dialect has a specific final sound /a/ as /o/ but not all final sound $/ a /$ is pronounced as $/ a /$. The final sound $/ r /$ is dropped down and the sound / $u /$ after the letter $\langle r\rangle$ is pronounced as / $\boldsymbol{w} /$ in some particular words. This phonemic system must be preserved and developed as a local knowledge. Modality change of consciousness happens to the Malay, and Indonesian becomes elitist and leaves the egalitarian Malay. This descriptive qualitative research concerned to the phonemic features and comprehensive picture of Malay contemporary sounds, and Malay vowels and consonants with the pertinent articulatory elements in Batam. Observation method with participatory technique involved in data collection taken from Kampong Tua Nongsa, Sanggau, Tanjung Uma, and Tanjung Riau. The theory to support the analysis was taken from Finegan and Low's theories in term of phonological and phonetic approach and supported by Kelly, McMahon, Roach, and Yule's theories. It is found that the letter $\langle a\rangle$ is pronounced as $/ \partial /$ in particular place. And $\langle u\rangle$ is pronounced as $/ p /$ in particular place. $/ R /$ in Malay is different from $/ r /$ in Indonesian and $/ b /$ in English as $/ R /$ is produced by uvula. The final consonant-closed sound $<k>$ and $<l>$ are not sounded as they are represented by /P/. Letter $\langle h\rangle$ is not pronounced as $/ \mathrm{h} /$ in the final $<\mathrm{h}>$ consonant-closed syllable sound. $/ \mathrm{f} /$, $|x /|$,$f / and / z /$, all these fricative sounds do not appear in Malay. The Malay pronounced them as $/ p /$ for $/ f /$ in maaf, $/ k /$ for $/ x /$ in ikhlas, /s/ for $/ f /$ in syukur, and $/ j /$ for $/ z /$ in izin. Syllable sound ends with letter $\langle b\rangle$ or $\langle d\rangle$ is not pronounced with end / $b /$ or $/ d /$ but it pronounces with end /p/ or /t/ such sebab as /sebıp/, sabtu as /sıpto/, wujud as /wrjot/, and sujud as / sojot/.
\end{abstract}

Keywords: Malay vowels and consonants; phonological and phonetic approach

Received:

11 April 2019
Revised:

14 August 2019
Accepted:

Published:

28 January 2020
29 February 2020 
Ambalegin, L., \& Arianto, T. (2020). Some negative contents portrayed in English song lyrics. EduLite: Journal of English Education, Literature, and Culture, 5 (1), 159-175.

\section{INTRODUCTION}

Batam is very well-known as a Negeri Melayu which has a specific characteristic in culture and tradition of Malay. The values of Malay culture are the foundation of life of the society. William (as cited in Aslan, 2017) stated that value is ".....what is desirable, good or bad, beautiful or ugly". Light, Keller, and Colhoun (as cited in Aslan, 2017) limited that Value is people's idea in term of the way to share goodness, badness, desire and undesire. Value transcends anyone particular situation. Value is the colour of people's overall way of life.

Batam is the most melting-pot city in Kepulauan Riau Province. Undeniably, Nowadays Batam as one of the fastest developed cities in the province welcomes thousand people from other provinces as this city needs employees for factories. The original culture of Batam, as a Negeri Melayu, becomes disappeared because of various issues in this globalization era. But it is needed to be appreciated that the government keeps concerning the Malay Culture. There are some kampong tua in Batam. Kampong tua keeps preserving the Malay Culture, and one of them is Malay. The residents of kampong tua still use Malay to communicate. Based on the interview, there were the interviewees from kampong tua Sanggau, Nongsa, Belian, Telok Air, and Tanjung Uma. They informed that it is the mother tongue used in their everyday communication. Mostly, kampong tua are located in the coastal areas in Batam. Known as an archipelago, the Malay seniors mostly work as fishermen. Historically, the European admitted that the Malay was able to sail, and Negeri Melayu meant the land which was surrounded by the seas (Dja'far as cited in Aslan, 2017).

Batam is not a newborn city. It has been developed since thousand years ago. History noted that Batam has been occupied since the year 231 (Dahlan, 2015). Suku Laut or Orang Selat lived in the coastal areas. Suku Sakai and Jakun lived on woodland. In 1790, the local, A'lama, married the Malay, and they opened the land known as Kampong Setenga. The Malay from Pahang opened the land named Patam in 1813. Meanwhile in 1817, the Chinese stayed in Sei Panas, Duriangkang, Muka Kuning, Tanjung Uncang, and Waheng. Generally, these kampongs firstly were built in the coastal area. The woodlands soon developed into cities with the business areas. The local then kept living in the coastal area. The kampong is nowadays known as a kampong tua.

The kampong tua brings the Malay Culture to the people. Government announced 33 kampong tua in Batam as a medium to preserve the local wisdom of Malay in Batam (Bbi/JPC, 2015). Kampong tua is the landmark of the Malay local wisdom. The existence of the local wisdom is reflected from the values in the society (Ridwan as cited in Kartikasari, Oramahi, \& Idham, 2017). Etymologically, wisdom is the ability of someone to use his/her mind to face any kind condition or situation. The values are brought into their life activity which is observed from their attitude (Aslan, 2017). Government commits to preserve Malay culture to balance the local wisdom that has been built long before. The sustainability of local wisdom is reflected in the values applied in a community. Wales (as cited in Brata, 2016) stated that local wisdom or local knowledge or local genius or cultural identity is the number of cultural characteristic which the huge majority of people have in prevalent 
view as a result of their experiences in everyday life. These values cannot be separated from the society's everyday activities. And Malay is never separated from the Malay's everyday activities.

The Malay is originated from Proto-Malay. It has been existed in western Kalimantan since 2000 years ago. The spread of the Malay was started in the year 100. They immigrated to Tambelan and Kepulauan Riau then to Malay Peninsula. The other Proto-Malay immigrated to Luzon and Maluku. In the other period, there was immigration sailed across Karimata Strait to Bangka and Belitung and western coast of Java, Jakarta (Collins as cited in Effendy, 2014). For some centuries, Malay developed as an everyday conversation in those areas. It was known also that Malay had been a lingua franca for all over South East Asia. The Catholic Priest Francois Valentijn who performed in Ambon from 1685 to 1695 and from 1707 to 1713 said Malay positively (Beschrijvinghe van Malakka), "Besides Portuguese, this language is beautiful, excellent, melodious, and rich; this language is used in Indies, Persia, Hindustan, and China" (Mahayana, 2009).

Since then, Malay played an important role in every aspect of the Malay's life. It touched the literary work. Malay literature contained of history, laws, and verses. Generation-to-generation repetitive aural-oral Malay literature was illustrated in myth, legend, and folktale. Written Malay literature was illustrated in magnificence, epic, and genealogy. Malay drama which explores the beauty of language aesthetically and artistically is also very famous such as Makyong, Mendu, and Bedande. Finally, there is pantun. It is The Malay famous repertoire classified as Malay didactic poem. Gurindam 12 is the famous Malay didactic poem (Akmal, 2015). All these literary works contain of moral values which are able to build up a good attitude and self-character (Effendy, 2014).

The function of Malay is not only as a tool of communication, more than that, Malay is a mother tongue, a proud, an identity, connectivity, and a culture support. The Malay explores and exploits the words, phrases, and sentences in different medium with aesthetic language structure. The ability of rhetoric in a Malay oral activity is to avoid the silly talk or heated discussion (Tambak \& Sukenti, 2017). Beating about the bush phenomenon (Osman as cited in Effendy, 2014), the Malay utterances show that they communicate in indirect speech act. Indirect speech act is the way to talk politely ((Leech, 2016). Speaking politely is the character of the Indonesian. Indonesia is famous with this character. This character represents the national character. National character is important to build up the nation. National character is an individual's attitude, habit, desire and inclination, opinions and views, hopes and inspiration, standards and motives, and ideas and beliefs that is shared to the other individuals of his nation (Kohn, 1982).

Character is a value that is applied in social daily activities. Character is categorized as the quality of personality. There are characteristics of character as follows (Mu'in as cited in Effendy, 2014). Character is;

1. what you are when nobody is looking at

2. a result of values and beliefs

3. a habit that becomes second nature

4. not a reputation or what others think about you.

5. not how much better you are than the others 
6. not relative

Character of Indonesia is every individual character. The Indonesia Character is related to the nation ideology. Pancasila is an Indonesian ideology. The Indonesia values are reflected in five principles of Pancasila.

Some information said that the root of Indonesian was Malay. It is said because Malay and Indonesian have the similarities in structural pattern, phonemic system, and vocabulary. A few monuments show the relevant information of Malay. The ancient inscriptions written on stones inform that Malay is as a tool of communication. The tombs of Kedukaann Bukit 683 and Talang Tuo 684 in Palembang, Kota Kapur 686 in West Bangka, and Karang Berahi, Bangko 688 in Jambi tell that the ancient Malay had been used in Sriwijayan era. The tombs of Gandasuli 832 in Central Java and Bogor 942 in Bogor show the inscription of ancient Malay. The inscription in the tomb of Kedukaan Bukit wrote (Nuryanto, 2015);

"Swastie syrie syaka warsaatieta 605 ekadasyii syuklapaksa wulan waisyakha dapunta hyang naayik di saamwan mangalap siddhayaatra di saptamie syuklapaksa wulan jyesta dapunta hyang marlapas dari minanga taamwan".

(Selamat! Pada tahun syaka 605 hari kesebelas pada masa terang bulan Waisyaakha, tuan kita yang mulia naik di perahu menjemput Siddhayaatra. Pada hari ketujuh pada masa terang bulan Jyestha, tuan kita yang mulia berlepas dari Minanga Taamwam.)

From the translation, the inscription written 1500 years ago has the similarity between Malay and Indonesian. The resemblance of the words on the inscription exists nowadays.

In Sriwijayan era, Malay was everyday language for the members of the society. Clearly, it was used as follows;

1. Literary language; the books of life rules and literary work

2. Lingua franca

3. Trade language in the coastal areas

4. Official language (Nuryanto, 2015).

The Malay shows the big number in Indonesia. The number of them in Indonesia is more than in Malaysia, Singapore, or in Brunei. Malay is uttered along the eastern coastal area of Sumatera and coastal area Kalimantan, Bengkulu, Kepulauan Riau, Jambi, Kepulauan Bangka Belitung, Sumatra Selatan, and Negara in Bali. Riau is the center of Malay literary work and culture. Riau Malay was developed from this province which is the core of other archipelago mother tongues such as in Indonesia, Malaysia, Singapore, Brunei Darussalam, part of Thailand, and part of Philippines. The development of Malay and Malay literature got their high reputation in the era of Riau Lingga Kingdom. Raja Ali Haji developed Malay in Pulau Penyengat. Soon, Malay experienced its glory in archipelago.

The development of science and technology brings the social and culture changes to the Malay. Some influences happened to the Malay. Modality change of consciousness happens to them, and Indonesian becomes elitist and leaves the egalitarian Malay. Unlike Indonesian and English, Malay as a mother tongue has no any formal course taught in schools, and not too many books discuss Malay. The young generation seldom speaks in Malay in Batam but luckily the seniors' Malay is still very thick. Malay is the heritage of 
Indonesia, and it is the people of Batam and Malay's responsibility to sustain it from the extinction in Negeri Melayu. Malay is a language that is created with values and identity and concerns to the rules of respect, appreciation, guidance, politeness, and tolerance. And it is true that Malay is the local wisdom of Indonesia.

Since language brings its own differences, the difference among the language makes the languages unique. Why the languages are unique because they have their own rules. The rules in language are in structural pattern, word formation, pronunciation, etc. It happens in every country that there is more than one language applied in. Every region in a country brings its own language instead of the national language and it is usually known as a mother tongue. Malay is one of the mother tongues in Indonesia. It has a unique pronunciation (segmental) and beautiful stress and intonation (suprasegmental). It is essentially a one-to-one relationship between spelling and pronunciation, and there will be the same number of phonemes used in the language as there are letters in the alphabet. It is called a 'phonetic' language (Kelly, 2004).

The high frequency of / / / appearance is the first impression while hearing Riau Malay subdialect kepulauan in Batam. Its dialect has a specific final sound /a/ as /o/ such as saya as /sayə/, apa as /apə/ but not all final sound /a/ is pronounced as / $/$ /. The final sound $/ \mathrm{r} /$ is dropped down and the sound $/ \mathrm{u} /$ after the letter $[\mathrm{r}]$ is pronounced as $/ \mathrm{p} /$ in some particular words such as telur as /talp/. This phonemic system in relation to consonant and vowel sounds is one interesting phenomenon to differ the concept of phonemes from the other mother tongues. To have the characteristics of Riau Malay subdialect kepulauan in Batam, it is very important to study the phonemic system. By doing this study, it can be identified the characteristic of the phonological system of Riau Malay subdialect kepulauan as a local knowledge in Batam, then frame it analytically in to Malay phonemes.

The sound of phoneme is not the same throughout languages. A sound might be a phoneme in a language but might not be so in another language. The sum of phonemes varies from one language to another language (Richards, Plat \& Weber as cited in Barman, 2009). Phonemes are written in International Phonetic Alphabet (IPA) conventionally. Phonemics studies the phonemes properties related to a language, that it is closely connecting to phonetics and phonology (Ladefoged, 2006). Odden (2005)stated that phonetics relates to the sounds meanwhile phonology deals with cognitive aspect of sounds. Being international, Malay basic sounds can be occurred in the IPA. It is an analytic framework for the study of speech segment.

Learning the phonemic system of Riau Malay sub-dialect kepulauan in Batam is very important in order to preserve this mother tongue as a local wisdom of Batam. One thing needed to be concerned is that there are Malay dialectal differences from one area of Kepulauan Riau to another. So, this research discussed the structure of oral Malay dialect in Batam in term of segmental phonemes. The investigation concerned to the phonemic features and comprehensive picture of Malay contemporary sounds in Batam. In conjunction to the phonemes, it also discussed the Malay vowels and consonants with the pertinent articulatory elements in Batam. 
To support this research, some experts' theories supported this research. This research adapted International Phonetic Alphabet (IPA). The IPA symbols are used as the standard for the speakers in pronouncing each distinct sound of a language (Skandera \& Burleigh, 2005). The phonetic alphabets represent the consonants. When symbols appear in pairs, the one to the right represents a voiced consonant and shaded areas denote articulation judge impossible (Ladefoged, 2006).

THE INTERNATIONAL PHONETIC ALPHABET (revised to 2005)

\begin{tabular}{|c|c|c|c|c|c|c|c|c|c|c|c|c|}
\hline \multicolumn{13}{|c|}{ CONSONANTS (PULMONIC) } \\
\hline & Bilabial & Labiodental & Dental & Alveolar & Post alveolar & Retroflex & Palatal & Velar & & Uvular & Pharyngeal & Glottal \\
\hline Plosive & $\mathrm{p} \mathrm{b}$ & & & $\mathrm{t} d$ & & t d & c $\mathrm{f}$ & k & & q $\mathrm{G}$ & & $?$ \\
\hline Nasal & $\mathrm{m}$ & $\mathrm{m}$ & & n & & $\eta$ & $\mathrm{j}$ & & $\eta$ & $\mathrm{N}$ & & \\
\hline Trill & B & & & $\mathrm{r}$ & & & & & & $\mathbf{R}$ & & \\
\hline Tap or Flap & & r & & I & & $\mathrm{r}$ & & & & & & \\
\hline Fricative & $\phi \beta$ & f $v$ & $\theta \quad \delta$ & S Z & $\int 3$ & S $Z_{i}$ & ç j & $x y$ & $Y$ & $\chi$ в & h $\mathrm{I}$ & h $\mathrm{h}$ \\
\hline $\begin{array}{l}\text { Lateral } \\
\text { fricative }\end{array}$ & & & & 13 & & & & & & & & \\
\hline Approximant & & $v$ & & $\mathbf{I}$ & & t. & $\mathrm{j}$ & & U & & & \\
\hline $\begin{array}{l}\text { Lateral } \\
\text { approximant }\end{array}$ & & & & 1 & & & $\Lambda$ & & $\mathbf{L}$ & & & \\
\hline
\end{tabular}

Figure 1. International Phonetic Alphabet (Ladefoged, 2006)

Consonants are sounds produced with a lot of tightness in the mouth as air comes up from the lungs and gets squashed. The consonants in English pronunciation is included in segmental phonemes (Low, 2015). A consonant is pronounced by a partial or complete close of vocal tract (Finegan, 2015). Speech sound is able to be characterized based on the articulatory properties. The consonants are described in three characteristics: voicing, place of articulation, and manner of articulation (Low, 2015). Place of articulation shows the different sound because of the airstream in the lips, oral cavity, nasal, pharynx and glottis (Low, 2015). According to Yule (2014), the seven kinds place of articulation; bilabials, labiodentals, dentals, alveolar, palatal, velar, and glottal. Manner of articulation is the way English consonants pronounced. According to Yule (2014), manner of articulation in consonants are consists of stops, affricative, nasal, liquid, fricative and glides.

Ladefoged (2006) described vowels in trapezium shape. The trapezium is the illustration of shape of tongue. 


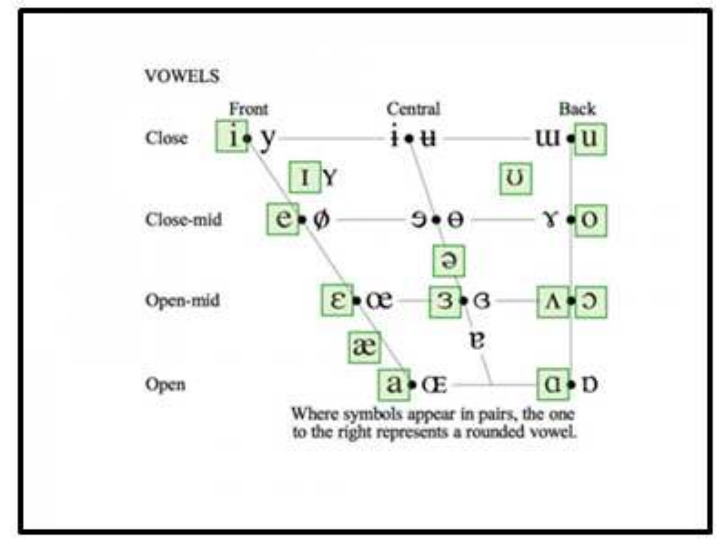

Figure 2. Cardinal vowels diagram (Ladefoged, 2006)

Low (2015) described that vowels are a production of sounds with relatively little obstruction in the vocal tract. According to Kelly (as cited in Ambalegin \& Arianto, 2018), based on the characteristics of the articulation, there are three categories vowel sounds; closed vowel sounds, mid vowel sounds, and open vowel sounds. Vowel phonemes discuss the 6 sections such as pure vowels, long and short vowel (vowel length), reduced vowel, nasalization, diphthongs, and triphthongs.

Kelly (as cited in Ambalegin \& Arianto, 2018) mentioned that diphthong is the combination of two vowels where tongue glides from one vowel articulation to another vowel position. There are three categories diphthong sounds; centering diphthongs, closing diphthong ending, and closing diphthong ending.

A triphthong is the combination of three vowel sounds where tongue rapidly and uninterruptedly moves away from first vowel articulation to another vowel position, then to a third vowel. Roach (2012) listed the triphthongs with five close diphthongs with schwa /ə/ eı (as in mayor, crayon), aı (as in choir, buyer), गә (as in loyal, royal), әซә (as in lower, mower), and avo (as in flower, coward).

\section{METHOD}

This research adapted the qualitative-descriptive method (Creswell, 2012). The data collection used the competence in observation method and participatory technique. Participatory technique involved in conversation (Sudaryanto, 2015). The data were taken by interviewing, noting, and recording the Malay seniors in each kampong tua related to segmental phonemic system of Riau Malay subdialect Kepulauan in Batam based on four different kampong tua represented south, north, west, east, and centre namely, Kampong Tua Nongsa, Sanggau, Tanjung Uma, and Tanjung Riau. The data were analyzed by identification the characteristic of the phonological system. The sounds produced by the Malay were explained related to articulatory properties and place of articulation in the vocal tract for the consonants and the anatomy of the vowels. Then, the phonemes were classified to map them based on the IPA. Finally, vowel and consonant phonemes of Riau Malay subdialect kepulauan in Batam were inventoried as the conclusion of the finding. 


\section{RESULT AND DISCUSSION Consonants}

a. Data 1: /b/ beli, biasa, tiba

/b/ is voiced bilabial plosive. It is produced by lower (labia) and upper (bi) lips. There is a stopping or blocking effect on the air stream in the opening (the small explosion of air when the lips open). There is vibration on the larynx. The lips close, the air flows from larynx freely and lets it go to the open lips abruptly. Then /b/ is produced with the vibrating larynx as the air passes through the open lips.

b. Data 2: /p/ pada, puasa tipu /p/ is voiceless bilabial plosive. It is produced by lower (labia) and upper (bi) lips. There is a stopping or blocking effect on the air stream in the opening. There is no vibration on the larynx. The lips close, the air flows from larynx freely and lets it go to the open lips abruptly. Then $/ \mathrm{b} /$ is produced as the air passes through the open lips.

c. Data 3: /m/ maya, macam, masa

$/ \mathrm{m} /$ is voiced bilabial nasal. It is produced by lower (labia) and upper (bi) lips. There is a stopping or blocking effect on the air stream in the closing. There is vibration on the larynx. The air flows from larynx to nasal cavity because the lips close. $/ \mathrm{m} /$ is produced as the air passes through the nose.

d. Data 4: /w/ lawa, wasiat, tawa,

/w/ is voiced bilabial approximant. It is produced by open and half close-shaped lips. The tongue glides with no touching any speech organs. There is vibration on the larynx. The lips shape $O$, and air flows from larynx to the lips, then /w/ is produced as the air passes through the half close-shaped lips.

e. Data 5: /f/ Farah, fitrah, Farida, Saiful, Fatimah

/f/ is voiceless labiodental fricative. It is produced by upper teeth and lower lip. There is a friction when the almost blocking air stream pushes through the very narrow opening. The air is blocked by the upper teeth and lower lip from the larynx, and the sound is produced when the air flows through the very narrow opening.

f. Data 6: /t/ tak, tepi, tingkap

$/ \mathrm{t} / \mathrm{is}$ voiceless alveolar plossive. It is produced by tip of the tongue on the alveolar ridge. There is a stopping or blocking effect on the air stream in the opening. The air from the larynx is blocked by tongue tip on the alveolar, and the sound is produced when the air flows out abruptly through the open free mouth.

g. Data 7: /d/ dapur, dosa, ada

/d/ is voiced alveolar plossive. It is produced by tip of the tongue on the alveolar ridge. There is a stopping or blocking effect on the air stream in the opening (tongue touches the tooth ridge and stop air. Move tongue away from the tooth ridge). The air from the larynx is blocked by tongue tip on the alveolar, and the sound is produced with the vibration larynx when the air flows out abruptly through the open free mouth.

h. Data 8: /n/ nampak, tanam, maknong 
$/ \mathrm{n} /$ is voiced alveolar nasal. It is produced by tip of the tongue on the alveolar ridge. There is a stopping or blocking effect on the air stream in the closing. There is vibration on the larynx. The air flows from larynx to nasal cavity because of the gap of the tongue tip on the alveolar ridge. $/ \mathrm{m} /$ is produced as the air passes through the nose.

i. Data 9: /1/ lima, lemak, talak

$/ 1 /$ is voiced alveolar lateral. It is produced by tip of the tongue on the alveolar ridge. There is vibration on the larynx. The air flows from larynx to oral cavity is blocked by the tongue tip on the alveolar ridge, then the air goes out from the sides of the tongue. $/ \mathrm{m} /$ is produced as the air passes through the sides of the tongue.

j. Data 10: /s / sisik, sibuk, pasar

/s / is voiceless alveolar fricative. It is produced by alveolar and front tongue. There is a friction when the almost blocking air stream is pushed through the very narrow opening. / s/ is produced when the air stream from the larynx makes a friction between front tongue and palate in the very narrow opening.

k. Data 11:/z/ zuhur, azab, Zubaidah, mubazir

$/ z /$ is voiced alveolar fricative. It is produced by alveolar and front tongue. There is a friction when the air stream from the vibrating larynx is pushed through the very narrow opening (push air through the gap). $/ z /$ is produced when the air from the larynx makes a friction between front tongue and palate in the very narrow opening. The sound is stopped when tongue tip is on the alveolar.

l. Data 12: / / isya, syahadat, syair, syawal

$<\mathrm{s}>$ and $\langle\mathrm{y}>$ cluster to make consonant cluster sound $/ \mathrm{J} / . / \mathrm{J} /$ is voiced alveolar fricative. It is produced by palate and front tongue. There is a friction when the air stream from the larynx is hissed through the very narrow opening. / $z$ / or long /s/ is produced when the air from the larynx flows freely and makes a friction between front tongue and palate in the very narrow opening to the O-shaped lips.

m. Data 13: /n/ tanya, minyak, nyata

$<\mathrm{n}>$ and $<\mathrm{y}>$ cluster to make consonant cluster sound $/ \mathrm{n} / . / \mathrm{n} /$ is voiced palatal nasal. It is produced by palate and front tongue. The air stream is blocked by the front tongue on the palate. /n/ is produced when the air partly goes to the open lips through the front tongue on the palate and the other part of the air goes to the nasal cavity.

n. Data 14:/j/ sekejap, jejaka, meja

/j/ is voiced palatal fricative. It is produced by palate and front tongue. The air stream is blocked by the front tongue on the palate. / $j /$ is produced when the air from the vibrating larynx makes friction and goes to the open lips through the front tongue on the palate.

o. Data 15: /ç/ campur, coba, macam, cantik

/ç/ is voiceless palatal fricative. It is produced by palate and front tongue. The air stream is blocked by the front tongue on the palate. /ç/ is produced when the air from the larynx mkes friction and goes to the open lips through the front tongue on the palate.

p. Data 16: /j/ layar, raya, maya 
$/ \mathrm{j} /$ is voiced palatal approximant. It is produced by halfclose-shaped lips. The tongue glides with no touching any speech organs. The air flows from the vibrating larynx to the lips. / $\mathrm{j} /$ is produced as the air passes freely through the opening palate and front tongue.

q. Data $17 ; / \mathrm{k} / \boldsymbol{k}$ ira, kasut, $\boldsymbol{k}$ atil

$/ \mathrm{k} /$ is voiceless velar plossive. It is produced by back of the tongue on the velar. There is a stopping or blocking effect on the air stream in the opening. The air from the larynx is blocked by back tongue on the velar, and $/ \mathrm{k} /$ is produced when the air flows out abruptly through the open free mouth.

r. Data 18; /g/ gila, gula, gamat

/g/ is voiceless velar plossive. It is produced by back of the tongue on the velar. There is a stopping or blocking effect on the air stream in the opening. The air from the larynx is blocked by back tongue on the velar, and /g / is produced when the air flows out abruptly through the open free mouth.

s. Data 19: / y/ tongkang, makngah, pingen

$<\mathrm{n}>$ and $<\mathrm{g}>$ cluster to make consonant cluster sound $/ \mathrm{g} / \mathrm{g} / \mathrm{g} /$ is voiced velar nasal. It is produced by velar and back tongue. The air stream is blocked by the back tongue on the velar. $/ \mathrm{n} /$ is produced when the air goes to the nasal cavity because of the gap of the tongue back on the velar.

t. Data 20: /R/ rumah, rusak, buruk

/ R/ is voiced uvular trill. It is produced by uvula and back tongue. The back tongue moves up to the uvula, the air flows freely to the side of back tongue and uvula at the same time the airflow trills the uvula to produce the voiced / R/

u. Data 21: / x/ Khairul, ikhlas,

$<\mathrm{k}>$ and $<\mathrm{h}>$ cluster to make consonant cluster sound $/ \mathrm{x} / . / \mathrm{x} /$ is voiced uvular fricative. It is produced by uvula and back tongue. The air flows by making a friction between uvula and tongue. / $\mathrm{x} /$ is produced when the air goes and vibrates the uvula. / $/$ / is the most difficult production of sound among the consonants.

v. Data 22: / / kecil, pihak, nak, minyak, kolik, budak

/?/ is voiceless glottal stop. / / mostly appears at the end of the syllable with $<\mathrm{k}>$ or $<1>$ end. These letters will not be sounded while being produced. / $/$ is produced when the syllable is sounded; the sound is ended by the air trapped in the larynx. The air cannot be flown out in the glottis.

w. Data 23: /h/ pihak, dahaga,zuhur

/h/ is voiced glottal fricative. / h/ does not involve the vocal tracts. / h/ is produced when the air from vibrating larynx makes a friction and flows freely to the halfopen lips. / h/ is the simplest production of sound

\section{Vowels} among the consonants

a. Data $1: / \Lambda /$ halal, dara, tak, buat

The tongue is in the central and the shape of the tongue is half open. $/ \Lambda /$ is produced in letter [a] at any position in the words. Letter $<a>$ is 
not pronounced as $/ \Lambda /$ when it positions in final vowel-close syllable sound but it is in final consonant-close syllable sound.

b. Data 2: /I/ tiba, tepi, tingkap, sini, hari

The tongue is in the front and the shape of the tongue is close. /I/ is produced in letter $<\mathrm{i}>$ at any position. Letter is not pronounced as /I/ when it positions in final consonant-close syllable sound.

c. Data 3: /v/ rumah, tua, puasa, busuk

The tongue is in the back and the shape of the tongue is half close. / / is produced in letter $[\mathrm{u}]$ at any position. / $v /$ is not pronounced when it positions in final consonant-close syllable sound.

d. Data 4: /e/ tengok, kereta, putih, bising, balik, bukit, kisah

The tongue is in the front and the shape of the tongue is half open. /e/ is produced in letters $<\mathrm{e}>$ and $<\mathrm{i}\rangle$. Letter $\langle\mathrm{e}\rangle$ is pronounced as /e/ and /ə/ such as in kereta as / kəRetə/. /e/ appears in the second syllable sound after / / / in the first syllable sound and /e/ appears in the first syllable sound if there is no another letter [e] after /e/. There is no /e/ in the final vowel-close syllable sound. /e/ is also pronounced when letter $<\mathrm{i}>$ is positioned in the final consonant-close syllable sound.

e. Data 5: /ə/ apa, tiba, cerita, kereta, betik, kenapa, kena,

The tongue is in the central and the shape of the tongue is half open. $/ \partial /$ is produced in letters $\langle e>$ and $<a>. / \partial /$ in the final syllable sound is the famous characteristic sound in Malay. / / / is pronounced when letter $\langle a\rangle$ is positioned in the final vowel-close syllable sound but not in the final consonant-close syllable sound. /o/ is also pronounced when $<\mathrm{e}>$ is positioned in the first syllable sound.

f. Data 6: /p/ boleh, bomo. rusak, rujak, atuk, betul,engkau, jantung, pancung, sulung, tidur, teruk

The tongue is in the back and the shape of the tongue is open. / $/$ is produced in letters $\langle 0\rangle$ and $\langle\mathrm{u}\rangle$. $\langle 0\rangle$ is pronounced as $/ \mathrm{p} /$ at any position. $<\mathrm{u}>$ is pronounced as $/ \mathrm{p} /$ when $<\mathrm{u}>$ is positioned in the final

\section{Semivowels} consonant-close syllable sound.

In Malay, there is no diphthong sound. Double vowels in a word produce a semi vowel sound. [u] and [i] produce sound $/ \mathrm{w} /$ and $/ \mathrm{j} /$

a. Data 1: / Ij $\Lambda /$ for $<\mathrm{ia}>$ tiada, biaya, siapa, sentiasa, biasa, dia The $<\mathrm{i}>$ and $<\mathrm{a}>$ cluster to make semi-vowel sound $/ \mathrm{j} /$ between $<\mathrm{i}>$ and $<\mathrm{a}>$. Biaya and dia is pronounced as $/ \mathrm{bIj} \wedge \mathrm{j} ə /$ and $/ \mathrm{dIj} /$.

b. Data 2: /Ijo/ for <iu> hiu, siul

The $<\mathrm{i}>$ and $<\mathrm{u}>$ cluster to make semi-vowel sound $/ \mathrm{j} /$ between [i] and [u]. Hiu is pronounced as / Ijv/.

c. Data 3: $/ \wedge \mathbf{j} /$ for $<$ ai $>$ gulai, duhai, wahai, pantai

The $<\mathrm{a}>$ and $<\mathrm{i}>$ cluster to make semi-vowel sound $/ \mathrm{j} /$ after $<\mathrm{a}>$. Gulai is pronounced as /gol $\mathbf{j} /$.

d. Data 4: / $\Lambda \mathrm{w} /$ for <au> kacau, silau, surau, bakau, kerbau, pisau The $<a>$ and $<u>$ cluster to make semi-vowel sound /w/ after <a>. Kacau is pronounced as $/ \mathrm{k} \wedge$ çı $/$.

e. Data 5: /wI/ for <ui> muih, buih

The $<\mathrm{u}>$ and $<\mathrm{i}>$ cluster to make semi-vowel sound /w/ between $<\mathrm{u}>$ and $<\mathrm{i}>$. Buih is pronounced as /bowI/. 
f. Data 6: /wı/ for <ua> puasa, kuasa, suami, tualah

The $<\mathrm{u}>$ and $<\mathrm{a}>$ cluster to make semi-vowel sound /w/ between $<\mathrm{u}>$ and $<\mathrm{a}>$. Tualah is pronounced as / tow $\mathrm{l}_{\Lambda} /$.

g. Data 7: /we/ for <ui> duit, kue

The $<\mathrm{u}>$ and $<\mathrm{i}>$ cluster to make semi-vowel sound /w/ between $<\mathrm{u}>$ and $<\mathrm{i}>$. Duit is pronounced as /dowet/.

h. Data 8: /wo/ or /wa/ for <ua > kuah, dua, tua

The $<\mathrm{u}>$ and $<\mathrm{a}>$ cluster to make semi-vowel sound /w/ between $<\mathrm{u}>$ and $<\mathrm{a}>$. Dua is pronounced as /dowə/.

i. Data 9: /wp/ for <au> laut,

The $<a>$ and $<u>$ cluster to make semi-vowel sound /w/ between $<a>$ and $<\mathrm{u}>$. Laut is pronounced as $/ 1 \Lambda \mathbf{w p t} /$.

j. Data 10: /wo/ for <au>, daun, mau

The $<\mathrm{a}>$ and $<\mathrm{u}>$ cluster to make semi-vowel sound $/ \mathrm{w} /$ between $<\mathrm{a}>$ and $<\mathrm{u}>$. Daun is pronounced as /dawon/.

k. Data 11: /je/ for <ai> air, lain, kain, main

The $<\mathrm{a}>$ and $<[\mathrm{i}>$ cluster to make semi-vowel sound /w/ between $<\mathrm{a}>$ and $<\mathrm{i}>$. Air is pronounced as $/ \Lambda \mathrm{je} /$.

In Malay, there are no three vowels in a word and semi vowel is not pronounced as a vowel sound. In fact, double vowels in a word are pronounced by inserting semivowel sound. Buaya/bowajə/, kaya /kajə/, kawan /kawan/, bawa /bawə/, biaya/bIjajə/ are the words in Malay pronounced by inserting $/ \mathrm{w} /$ and $/ \mathrm{j} /$.

\section{Consonants}

a. There are 23 consonants in Malay; 14 voiced consonants (/b/, /d/, /g/, $/ \mathrm{z} /, / \mathrm{m} /, / \mathrm{n} /, / \mathrm{n} /, / \mathrm{n} /, / \mathrm{j} /, / \mathrm{x} /, / 1 /, / \mathrm{R} /, / \mathrm{w} /$, and $/ \mathrm{j} / \mathrm{l}$ and 9 voiceless consonants $(/ \mathrm{p} /, / \mathrm{t} /, / \mathrm{c} /, / \mathrm{k} /, / \mathrm{f} /, / \mathrm{s} /, / \mathrm{f} /, / \mathrm{P} / \mathrm{s}$, and $/ \mathrm{h} /)$.

b. There are 6 kinds place of articulation in Malay; bilabials, labiodentals, alveolar, palatal, velar, and glottal.

c. Manners of Articulation in Malay are plosive and stop, nasal, fricative, liquid, approximant, and trill.

d. Articulation positions are lips, teeth, tongue, palate, uvula, and glottis.

e. There is a one-to-one relationship between spelling and pronunciation, and there is the same number of phonemes used in the language as there are letters in the alphabet.

f. Every letter in the alphabet represents one sound, and each letter would be a phonetic symbol, and each sound has its appropriate symbol.

g. There are two consonants represent one phoneme; <ng $>$ for $/ \mathrm{y} /,<\mathrm{kh}>$ for $/ \mathrm{x} /,<$ ny $>$ for $/ \mathrm{n} /$, and $<$ sy $>$ for $/ \mathrm{f} /$.

h. Arabic is one of the foreign languages whose vocabulary is borrowed in Malay, such as fitrah, zuhur, khalik, and syawal (Dahlan, 2015). There are some borrowing words mostly from Arabic that make sound /f/, $/ \mathrm{x} /, / \mathrm{J} /$ and $/ \mathrm{z} /$. All these fricative sounds do not appear in Malay. The Malay pronounce them as /p/ for /f/ in maaf, /k/ for / $/$ in ikhlas, $/ \mathrm{s} /$ for $/ \mathrm{J} /$ in syukur, and $/ \mathrm{j} /$ for $/ \mathrm{z} /$ in izin. 
i. / R/ in Malay is different from / $\mathrm{r} /$ in Indonesian and / $/$ / in English. It is because / $R /$ is produced by uvula.

$\mathrm{j}$. /R/ is silent when its position is in final $[\mathrm{r}]$ consonant-close syllable sound.

$\mathrm{k} . / \mathrm{P} / \mathrm{is}$ a sound appeared in the end of syllable sound. The final $<\mathrm{k}>$ or $<1>$ consonant-close syllable sound is not sounded as [k] and [1] are represented by / $\mathrm{P} /$ such as /t $\Lambda$ ? / in tak, /kecl?/ in kecil. Final <k> and $<1>$ are not pronounced.

1. Letter $\langle\mathrm{h}\rangle$ is omitted as a sound when $<\mathrm{h}\rangle$ is positioned in the end of the final syllable such as in putih and kisah. Final $<\mathrm{h}>$ in the word is not also pronounced when it is followed by another consonant such as in sembahyang.

m.Plosive could not appear as a close of final syllable.

$n$. Syllable sound ends with letter $\langle\mathrm{b}\rangle$ or $\langle\mathrm{d}\rangle$ is not pronounced with end /b/ or /d/ but it pronounces with end /p/ or /t/ such sebab as /seb $\Lambda \mathbf{p} /$, sabtu as /s $\Lambda \mathbf{p t o / , ~ w u j u d ~ a s ~ / w o j o t / , ~ a n d ~ s u j u d ~ a s ~ / s o j o t / ~}$

Table 1. Malay Phonetic Alphabet

\begin{tabular}{|c|c|c|c|c|c|c|c|c|}
\hline & Bilabial & Labiodental & Dental & \begin{tabular}{|l|} 
Alveolar \\
\end{tabular} & Palatal & Velar & Uvular & Glottal \\
\hline Plosive & $\mathrm{p}$ & & & $t$ & & $\begin{array}{ll}\mathrm{k} & \mathrm{g} \\
\end{array}$ & & $?$ \\
\hline Nasal & $\mathrm{m}$ & & & $\mathrm{n}$ & $\mathrm{n}$ & n & & \\
\hline Trill & & & & & & & $\mathrm{R}$ & \\
\hline Fricative & & $f$ & & $\mathrm{~s}$ & j & & $\chi$ & $\mathrm{h}$ \\
\hline Approximant & $\mathrm{w}$ & & & & $\mathrm{y}$ & & & \\
\hline $\begin{array}{l}\text { Lateral } \\
\text { Approximant }\end{array}$ & & & & 1 & & & & \\
\hline
\end{tabular}

\section{Vowels}

a. There are 6 vowels in Malay $/ \mathrm{I} /, / \mathrm{p} /, / \mho /, / \Lambda /, / \mathrm{e} /$, and $/ \curvearrowright /$

b. The type of the vowel is short vowel type.

c. Based on the height, the positions are close, half-close, half-open, and open.

d. Based on the location of the tongue, the positions are front, central, and back

e. There are rounded and unrounded vowels.

f. /I/ is represented by letter $<\mathrm{i}>, / \mathrm{p} /$ by letters $<\mathrm{o}>$ and $<\mathrm{u}\rangle, / \mathrm{v} /$ by letter $<\mathrm{u}>, / \Lambda /$ by letter $<\mathrm{a}>$, /e/ by letters $<\mathrm{e}>$ and $<\mathrm{i}>$, and $/ \mathrm{\rho} /$ by letters $<\mathrm{a}>$ and $<\mathrm{e}>$.

g. $/ \mathrm{p} /, / \mathrm{e} /$, and $/ \mathrm{o} /$ have two letters for each to be pronounced.

$\mathrm{h}$. Letter $<\mathrm{a}>$ is pronounced as $/ \partial /$ in final [a] vowel-close syllable sound.

i. Letter $\langle\mathrm{u}\rangle$ is pronounced as $/ \mathrm{p} /$ in final consonant-close syllable sound.

j. Letter $<\mathrm{i}>$ is pronounced as /e/ in final consonant-close syllable sound.

$\mathrm{k}$. Letter $<\mathrm{e}>$ is pronounced as $/ \mathrm{e} /$ in second syllable sound after $/ \mathrm{o} /$ in first syllable sound.

1. Letter $\langle\mathrm{e}>$ is pronounced as $/ \curvearrowright /$ in first syllable sound and in first syllable sound before /e/ in second syllable sound. 


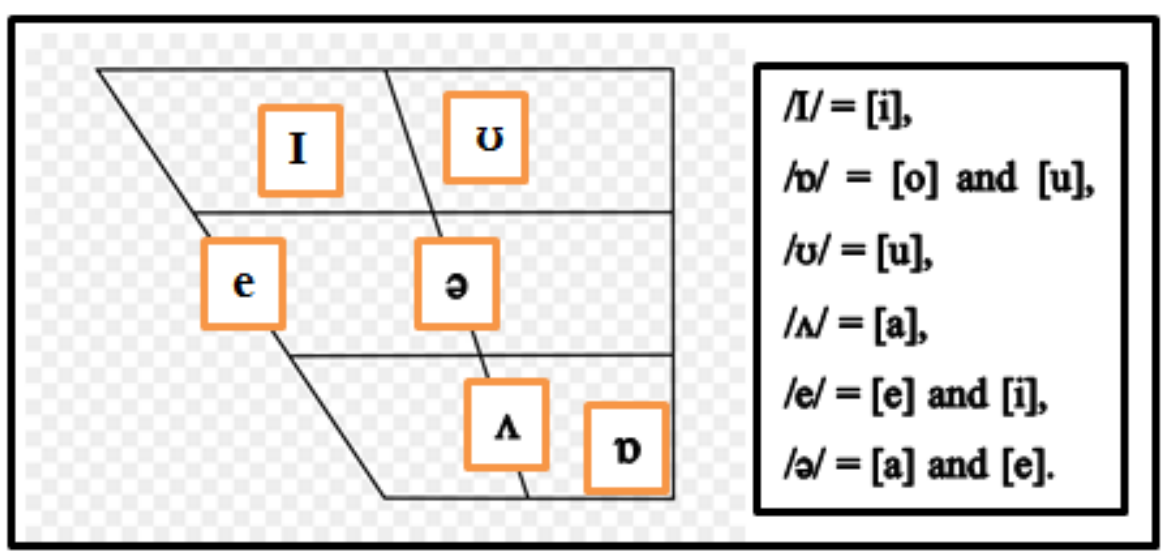

Figure 3. Malay Vowels Diagram

\section{Semivowel sounds}

a. Semivowel sounds $/ \mathrm{w} /$ and $/ \mathrm{j} /$ are very clear pronounced in words. Besides letters $<\mathrm{w}>$ and $\langle\mathrm{y}>$ pronounced as $/ \mathrm{w} /$ and $/ \mathrm{j} /$, there are a few double vowels pronounced with semivowel sound; $<\mathrm{ia}>,<\mathrm{iu}>,<\mathrm{ai}>$, $<$ au $>$, <ui $>$, <ua $>$.

b. $/ \mathrm{j} /$ is pronounced between letters $<\mathrm{i}>$ and $<\mathrm{a}>,<\mathrm{i}>$ and $<\mathrm{u}>$, and $<\mathrm{a}>$ and $<\mathrm{i}>$

c. /w/ is pronounced between letters $<\mathrm{a}>$ and $<\mathrm{u}\rangle,<\mathrm{u}\rangle$ and $<\mathrm{i}>$, and $<\mathrm{u}>$ and $<\mathrm{a}>$

d. Letter $<\mathrm{i}>$ produces $/ \mathrm{j} /$ and letter $<\mathrm{u}>$ produces $/ \mathrm{w} /$.

e. Letter $\langle\mathrm{y}\rangle$ is not pronounced as /i/ in words and $\langle\mathrm{w}\rangle$ is not pronounced as $/ v /$ in words.

f. A few Malay words which contain double vowels is pronounced with no semivowel sound sich as faedah $/ \mathrm{f}_{\Lambda}-\mathrm{ed} \Lambda /$, doa $/ \mathrm{dp}-\Lambda /$, and syair $/ \int_{\Lambda-}$ IR/.

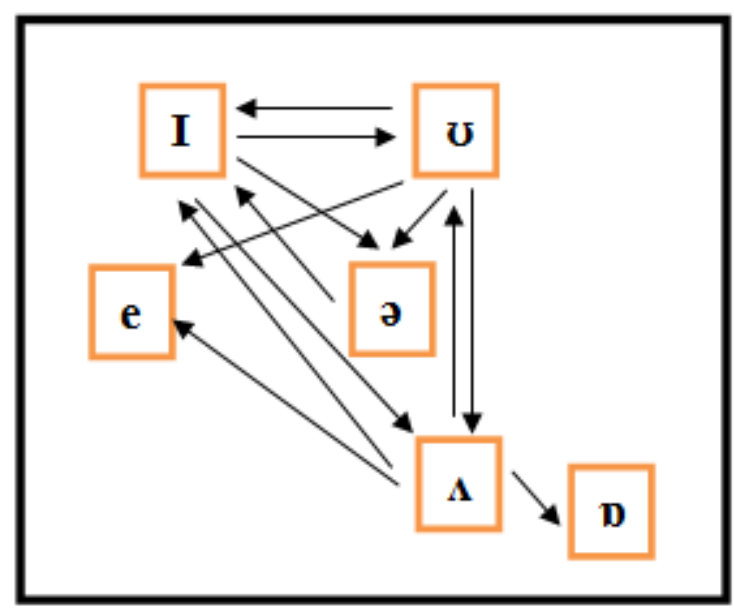

Figure 4. Malay Semivowel Sounds between Vowels Diagram 


\section{CONCLUSION}

Malay is a polite language. It is produced with beautiful intonation because it is pronounced with lax muscle. Malay is a good example of 'phonetic' language. In producing the consonants sounds, there is essentially a one-toone relationship between spelling and pronunciation, and there will be the same number of phonemes used in the language as there are letters in the alphabet. Every letter in the alphabet represents one sound, and each letter would be a phonetic symbol, and each sound has its appropriate symbol.

Vowel sounds are very unique while pronouncing. Vowel sounds is not called one-to-one relationship between spelling and pronunciation. The letter $<a>$ is pronounced as $/ \partial /$ in particular place. And $<u>$ is pronounced as $/ p /$ in particular place. While pronouncing the vowels, vocal tracts are not involved, but vowels construct syllable. Vowel sounds involve the lips' shapes. The air flows out freely from the glottal to the lips, and then the lips shape based on the vowel sounds which are produced.

The final sound / / / mostly appears in Malay. / / is the sound characteristic of Malay. / / / is produced in the final $<a>$ vowel-closed syllable sound with letter $<a>$ then the letter $<a>$ is pronounced as $/ \curvearrowright /$. The letter $<a>$ will pronounce as $/ \Lambda /$ in the final consonant-closed syllable sound as in dara pronounced as $/ \mathrm{d} \Lambda \mathrm{R} \partial /$ and darah pronounced as $/ \mathrm{d} \Lambda \mathrm{R} \Lambda /$.

/R/ in Malay is different from / $\mathrm{r} /$ in Indonesian and / в/ in English. It is because /R/ is produced by uvula. /R/ is pronounced softly and it is sometimes not sounded clearly. Malay / R/ is also one of sound characteristics in Malay. And / $\mathrm{P} /$ is a sound appeared in the end of syllable sound. The final consonant close sound $<\mathrm{k}>$ and $<1>$ are not sounded as they are represented by / $/$ such as / $\mathrm{t} \Lambda$ ? / in tak and / kecI?/ in kecil. Then final $<\mathrm{k}>$ and $<\mathrm{l}>$ are not pronounced. Then, letter $<\mathrm{h}>$ is not pronounced as $/ \mathrm{h} /$ in the final $<\mathrm{h}>$ consonant-close syllable sound as in getah /get $\Lambda$.

The Malay cannot be separated from the influence of Islam. In the beginning of twentieth century, Malay became modern language (Dahlan, 2015). Arabic is one of the foreign languages whose vocabulary is borrowed in Malay, such as fitrah, zuhur, khalik, and syawal (Dahlan, 2015). There are some borrowing words mostly from Arabic that make sound /f/, /x/, / $/$ and $/ z /$. All these fricative sounds do not appear in Malay. The Malay pronounced them as /p/ for /f/ in maaf, /k/ for /x/ in ikhlas, /s/for / $/$ in syukur, and $/ \mathrm{j} /$ for $/ z /$ in izin.

\section{REFERENCES}

Akmal, A. (2015). Kebudayaan melayu Riau (pantun, syair, gurindam). Risalah, 26(4), 159-165. Retrieved from http://ejournal.uinsuska.ac.id/index.php/risalah/article/view/1283

Ambalegin, \& Arianto, T. (2018). English vowels and consonants mispronunciation of the seventh president of Republic of Indonesia in his official English speeches and its influencing factors. Langauge Literacy, Journal of Linguistics, Literature, and Language Teaching, 2(2), 113-128. https://doi.org/http://dx.doi.org/10.30743/11.v2i2.678

Aslan. (2017). Nilai-nilai kearifan lokal dalam budaya pantang larang suku 
Melayu Sambas. Ilmu Usuluhudin, 16(1), 11-20. https://doi.org/10.18592/jiiu.v16i1.1438

Barman, B. (2009). A contrastive analysis of English and Bangla phonemics. The Dhaka University Journal of Linguistics, 2(4), 19-42. https://doi.org/10.3329/dujl.v2i4.6898

Bbi/JPC. (2015, April). Kearifan lokal tetap dijaga dalam pengembangan Batam sebagai kota cerdas. Dinamika Kepri News. Retrieved from http://www.dinamikakeprinews.co/2015/04/kearifan-lokal-tetapdijaga-dalam.html

Brata, I. B. (2016). Kearifan budaya lokal perekat identitas bangsa. Jurnal Bakti Saraswati, 5(1), 9-16. Retrieved from https://ojs.unmas.ac.id/index.php/Bakti/article/view/226

Creswell, J. W. (2012). Educational research; planning, conducting, and evaluating quantitative qualitative research (4th ed.). Boston: Pearson Education Inc.

Dahlan, A. (2015). Sejarah Melayu (Second Ed.). Jakarta: PT. Gramedia Jakarta.

Effendy, C. (2014). Peranan sastra dan bahasa Melayu dalam membangun karakter bangsa. Jentera, 2(3), 126-134. https://doi.org/https://doi.org/10.26499/jentera.v3i2.443

Finegan, E. (2015). Language; Its structure and use (7th ed.). Stamford: Cengage Learning.

Kartikasari, D., Oramahi, H. A., \& Idham, M. (2017). Kearifan lokal masyarakat kelurahan Pasiran dalam pengelolaan hutan kota Gunung Sari kota Singkawang. Jurnal Hutan Lestari, 5(2), 375-381. Retrieved from

http://jurnal.untan.ac.id/index.php/jmfkh/article/viewFile/19984/164 14

Kelly, G. (2004). How to teach pronunciation. England: Pearson Education Limited. Retrieved from www.longman.com

Kohn, H. (1982). Nationalism: Its meaning and history. Florida: Robert E. Krieger Publishing Company, Inc.

Ladefoged, P. (2006). A course of phonetics (5th ed.). Boston: Thomson Wadsworth.

Leech, G. N. (2016). Principles of pragmatics. United Kingdom: Routledge.

Low, E. L. (2015). Pronunciation for English as an international language (1st ed.). New York: Routledge Publishers.

Mahayana, S. (2009). Perkembangan bahasa Indonesia-Melayu di Indonesia dalam konteks sistem pendidikan. Insania, 14(3), 395-424. https://doi.org/ 10.24090/insania.v14i3.350

Nuryanto, T. (2015). Menurunnya penutur bahasa Indonesia sebagai lingua franca. Journal Indonesian Language Education and Literature, 2(2), 4- 
12. https://doi.org/http://dx.doi.org/10.24235/al.ibtida.snj.v2i2.124

Odden, D. (2005). Introducing phonology. New York: Cambridge University Press.

Roach, P. (2012). English phonetics and phonology; A practical course (4th ed.). Cambridge, UK: Cambridge University Press.

Skandera, P., \& Burleigh, P. (2005). A manual of English phonetics and phonology. Germany: Gunter Narr Verlag Tubingen.

Sudaryanto. (2015). Metode dan aneka teknik analisis bahasa. Yogyakarta: Duta Wacana University Press.

Tambak, S., \& Sukenti, D. (2017). Implementasi budaya Melayu dalam kurikulum pendidikan Madrasah ibtidaiyah di Riau. Miqot, XLI(2), 362383.

Retrieved

from https://www.researchgate.net/publication/324008972

Yule, G. (2014). The study of language (5th ed.). New York: Cambridge University Press. 